\title{
ВАЛІДНІСТЬ ТА ЛОГІКА АНКЕТУВАННЯ В ПРОЦЕСАХ ПРИЙНЯТТЯ РІШЕНЬ
}

\author{
О. П. Мінцер, Н. О. Сінєнко \\ Національний університет охорони здоров'я України імені П. Л. Шупика \\ ${ }^{1}$ Міністерство охорони здоров'я України
}

\begin{abstract}
Розглянуто питання призначення, технологічної організації та доцільності проведення анкетування для забезпечення трансореру знань. Дослідження спрямовано на визначення ролі анкетування в навчальному процесі. В результаті дослідження з'ясовано, що анкетування - складний структурований процес, який має своє функціональне призначення, концептуальні положення, методологію, принципи оброблення отриманих даних. Стохастичне використання анкетування задля анкетування приносить лише шкоду. Дослідницька фрункція анкетування передбачає наявність обґрунтованого алгоритму проведення дослідження, спрямованого на вивчення думок, відношень респондентів проблеми, що вивчається, та проведення прямих і непрямих вимірів. Пропонується змінити логіку конструювання та оброблення даних анкет. Серед переліку запитань важливо забезпечити повторення фрагментів, що направлені на виявлення конкретного фракту чи явища, але висловлені іншими словами. Тоді створюється можливість оцінювання валідності опитування саме відносно процесу, що цікавить дослідника.
\end{abstract}

Ключові слова: критичне мислення, процедура опитування, стратегії анкетування, когнітивна інсрорматика, процеси пізнання, прийняття рішень, взаємодія людини та комп'ютера.

\section{VALIDITY AND LOGIC OF QUESTIONNAIRES IN DECISION-MAKING PROCESSES}

\author{
O. P. Mintser, N. O. Sinienko \\ Shupyk National Healthcare University of Ukraine \\ ${ }^{1}$ Ministry of Healthcare of Ukraine
}

Background. The issues of purpose, technological organization and expediency of conducting a questionnaire to ensure knowledge transfer are considered. The purpose of the study was to determine the role of questionnaires in the educational process.

Materials and methods. Results. Questionnaire - a complex structured process that has its own functional purpose, conceptual provisions, methodology, principles of processing the results. The stochastic use of questionnaires for questionnaires is only harmful. The research function of the questionnaire involves the existence of a sound algorithm for conducting research aimed at studying the opinions, attitudes of respondents to the problem under study and direct and indirect measurements.

Conclusions. It is proposed to change the logic of designing and processing data from questionnaires. Among the list of questions, it is important to ensure the repetition of fragments that are aimed at revealing a specific fact or phenomenon, but expressed in other words. Then it is possible to assess the validity of the survey in relation to the process of interest to the researcher.

Key words: critical thinking, survey procedure, questionnaire strategies, cognitive informatics, cognitive processes, decision making, human-computer interaction.

\section{ВАЛИДНОСТЬ И ЛОГИКА АНКЕТИРОВАНИЯ В ПРОЦЕССАХ ПРИНЯТИЯ РЕШЕНИЙ}

\author{
Национальный университет здравоохранения Украины имени П. Л. Шупика \\ ${ }^{1}$ Министерство здравоохранения Украины
}

\begin{abstract}
Рассмотрены вопросы назначения, технологической организации и целесообразности проведения анкетирования для обеспечения трансорера знаний. Исследование направлено на определение роли анкетирования в учебном процессе. В результате исследования установлено, что анкетирование - сложный структурированный процесс, имеющий свое функциональное назначение, концептуальные положения, методологию, принципы обработки полученных результатов. Стохастическое использования анкетирования для анкетирования приносит только вред. Исследовательская фрункция анкетирования предполагает наличие обоснованного алгоритма проведения исследования, направленного на изучение мнений, отношения респондентов к изучаемой проблеме, проведения прямых и косвенных измерений. Предлагается изменить логику конструирования и обработки данных анкет. Среди перечня вопросов важно обеспечить повторение фррагментов, направленных на выявление конкретного фракта или явления, но высказанных, другими словами. Тогда создается возможность оценки валидности опроса относительно процесса, который интересует исследователя.
\end{abstract}

Ключевые слова: критическое мышление, процедура опроса, стратегии анкетирования, когнитивная информатика, процессы познания, принятие решений, взаимодействие человека и компьютера.

(C) О. П. Мінцер, Н. О. Сінснко 
Вступ. Відомо, що анкетування - один із механізмів оцінювання ситуації або процесу, перевірки гіпотези та прийняття рішення, що найбільш часто використовується, а сама анкета може бути корисним інструментом збору інформації. Опитування також $€$ потужним інструментом стимулювання та підтримки критичного мислення. Будучи активним елементом у всьому процесі викладання та навчання, опитування створює активний інтерфейс між тими, хто навчається, та викладачами.

Вважається, що анкетування $є$ найбільш гнучким інструментом, що має унікальну перевагу перед іншими при збиранні як якісної, так і кількісної інформації. Останнім часом логіка анкетування стала особливо важливою та популярною практично в усіх технологічних вимірах щодо якості навчання, якості надання медичної допомоги, якості управління тощо. На жаль, в більшості випадків використання цього інструменту здійснюється без потрібного планування, без необхідного оброблення отриманих даних і без професійної організації процесу анкетування.

Мета роботи: визначити роль анкетування в навчальному процесі.

Результати та їх обговорення. В освітніх дослідженнях опитувальник складається із запитань або тверджень, на які просять надати відповідь. Часто вони носять досить поверхневий характер і стосуються традиційних фактів, думок, поглядів або переваг респондентів. У той же час, професійне анкетування вимагає багато часу, винахідливості та напруженої роботи.

Підкреслимо, що в описових дослідженнях, де джерела різноманітні та широко розповсюджені, опитувальник є основним інструментом збору даних. Він може використовуватися в широкому діапазоні територій (національному чи міжнародному), а методи дослідження стають все більш і більш удосконаленими.

В аналізі навчального та інших процесів анкета, виступає як вимірювальний інструмент. Відповідно, анкетування повинне, в першу чергу, відповідати критеріям якості. 3 цією метою більшість авторів пропонує користуватися обгрунтованістю (валідністю) та надійністю процесу, що вимірюється. В свою чергу валідність, тобто еквівалентність вимірювань характеристикам об’єкту, складається з низки окремих показників, що включають різні сторони процесу: змістовна валідність, зовнішня, емпірична; концептна (дискримінантна) валідність, прогностична валідність тощо.

Досить часто використовується завдання забезпечення емпіричної валідності, що є однією з найбільш важливих при розробленні нової анкети або адаптації апробованої за кордоном перекладеної анкети до регіональних умов та специфіки сприйняття респондентами. Для встановлення відповідності отриманих результатів «золотим» стандартом являється проведення «пілотного» дослідження, в ході якого респонденти оцінюють одне й те саме явище або процес за допомогою двох альтернативних анкет: авторської і вже апробованої.

Зрозуміло, що має бути обгрунтований алгоритм проведення дослідження, спрямованого на вивчення думок, відношення респондентів до конкретної проблеми анкетування, проведення прямих і непрямих вимірів.

Особлива парадигма викладання, що роками домінувала в освіті, представляла трансфер знань як просте передавання явищ, фактів, законів тощо. Вважалося, що потім ті, хто навчаються, самостійно уніфікують, класифікують та відсортують отримані знання. Зрозуміло, що анкетування цього процесу, який характеризується своїм подвійним характером, мало певні особливості, абсолютно не схожі з тенденціями сьогодення. В даний час, коли обсяги інформації безперервно збільшуються, а освітній процес приймає складний характер із елементами неформального та інформального навчання, трансдисциплінарністю фахових предметів і переривчастими циклами передавання знань, анкетування теж стає складною процедурою. Анкети містять велику кількість окремих складових - пунктів, питань, тверджень, кожне 3 яких направлено на непряме виявлення якогось окремого фрагмента загального цілого, внаслідок чого воно є частковим індикатором вимірюваного шкалою фактору (властивості, явища, процесу). Вважається що узгоджений інструмент повинен складатися з внутрішньо несуперечливих пунктів, які визначають щось єдине. Відповідно пропонується змінити логіку конструювання та оброблення даних анкет. Серед переліку запитань важливо забезпечити повторення фрагментів, що направлені на виявлення конкретного факту чи явища, але 
висловлені іншими словами. Тоді створюється можливість оцінювання валідності опитування саме відносно процесу, що цікавить дослідника.

Для оцінювання надійності (узгодженості) процедури анкетування застосовуються кілька методів. Головним методом $\epsilon$ перевірка того, що значення показників при проведенні вимірювань, по-перше, мають невелику випадкову помилку (статистична надійність анкети), по-друге, дійсно вимірюють те, що необхідно виміряти (валідність).

Елементи формальної організації, такі як політика, системи, процедури, процеси, форуми, мають певне значення для їх поведінки по відношенню до анкетування. Але вони також підкреслювали різницю між правилами та процесами, формально документально оформлених, а також правилами та процесами на практиці.

Окремо слід розглядати логіку голосового анкетування. Голосове анкетування часто не є результатом прямого застосування правил: вони зазвичай вимагають тлумачення в контексті конкретного питання, що викликає заклопотаність, а також глибокого знання неформальної організації. Неузгодженість у тому, яким чином класифікуються проблеми та приймаються заходи, також очевидні: використання формально запропонованих механізмів для деяких видів проблем навряд чи призведе до дії, а іноді навіть до визнання. Особливої уваги потребують питання структурування анкети/опитувальника.

Структура анкети. Вочевидь, зміст анкети для досягнення заявленої мети має сприяти отриманню найбільш повної інформації. У той же час, анкета повинна бути оптимальною як за складністю питань, так і за їхньою кількістю. Основним питанням, котре при цьому виникає: що мається на увазі під терміном «актуальність»? Відповідь - складність питання та кількість питань - далеко не повністю характеризує цю актуальність. По-перше, зовсім не очевидним $є$ зміст терміну «складність». Досвід спеціалістів, які займаються анкетуванням свідчить, що під складністю питання розуміється відносна кількість опитуваних, які правильно зрозуміли питання [8].

Незважаючи на не дуже коректні питання та бажання оцінити не тільки діяльність педагога, а й його людські якості. Крім того, одержувані результати мають дозволяти виявляти ті чи інші тенденцій. Проте результати анкетування часто викликають обурення деяких педагогів, які отримують низькі бали та намагаються шукати коріння проблеми не в собі, а в інших [9].

Сьогодні в процесі освіти студентів, післядипломної підготовки лікарів і провізорів, безперервного професійного розвитку спеціалістів беруть участь десятки людей. Процес осмислення навчального матеріалу відбувається, в тому числі, й поза стінами навчальних закладів. Зовсім інші люди, комп'ютерні системи управління навчанням, пошукові системи пояснюють нові концепції або правила, роз'яснюють сум'яття, розкривають таємниці, просячи додатковий час, вкладений у запитання, щоб покращити здатність осіб, які навчаються, розуміти навколишній світ.

Абсолютне необхідним являється вивчення шляхів і стратегії, що доступні для викладачів, схем організації та управління навчальним процесом для найкращого навчання студентів. В основу навчання має бути покладена здатність осмислювати навчальний матеріал, видобувати та перетворювати нові знання. Вкрай необхідними стають технології розвитку талантів і здібностей суб'єктів навчання для їх функціонування в реальному професійному середовищі. Саме для цього вони повинні вчитися в навчальних ситуаціях, максимально наближених до реального світу, а також таких, що заохочують студентів до активної участі. Найкращим інструментом якості виконання стратегічних завдань передавання знань і стає анкетування. Саме в цьому (а не в десятках анкет, що розробляються часто в ЗВО чи пропонуються різними управлінськими структурами) ми бачимо реальні завдання сучасного анкетування. На думку авторів, важливим являється також анкетування по виявленню шляхів мотивації людей для постійного навчання.

У перспективі планується зіставляти отримані оцінки студентів із результатами самооцінювання та оцінювання колег.

Слід підкреслити, що навіть протягом одного заняття завдання опитування можуть розрізнятися, як і загальні та конкретні цілі, пов'язані з опитуванням. На вступній частині анкетування допомагає налагодити людські контакти; виявити рівень базисних знань, розуміння нових проблем, що ведуть до теми. Наступні опитування мають підтримувати інтерес і пильність; заохочувати міркування та логічне мислення; виявляти порозуміння. Нарешті, опитування повинно змусити суб'єктів навчання 
переглянути результати кінцевих тестів і заохотити до дискусії.

У глобальному сенсі анкетування має багато функцій, оскільки являється невід’ємною частиною будь-якого процесу передавання знань, циклу визначених занять.

1. Соціальна функція: анкетування створює співпрацю між викладачами та студентами, у відповідних групах. Хороша відповідь приносить задоволення. Викладачі просять налагодити стосунки зі своїми студентами та намагаються зменшити соціальний розрив між ними.

2. Психологічна функція: анкетування допомагає розвивати та підтримувати здоровий емоційний та інтелектуальний клімат, а також встановлювати відповідні рівні мотивації.

3. Виховна функція: оскільки при анкетуванні перевіряються попередні знання, рівень засвоєння та розуміння, то воно допомагає кількісно оцінити попереднє навчання та закріпити останній процес навчання. Це систематизує отримані знання. Чим більше студентів братиме участь у взаємодії, тим більш активною та позитивною буде атмосфера передавання знань і успішнішим буде весь процес передавання знань.

Резюмуючи викладене зазначимо, що анкетування має обов’язкові етапи: 1. Розроблення оцінювання опитування. 2. Обговорення з респондентами можливості опитування. 3. Оцінювання діяльності, пов’язаної з етапною корекцією анкетування. 4. На заключному етапі формулювання рекомендацій стосовно вдосконалення наступних процесів опитування. В іншому випадку час роботи з анкетою буде затягуватися, суттєво зменшиться можливість об’єктивної та зваженої відповіді на кожне питання.

Підкреслимо також, що важливим моментом у визначенні ступеня задоволеності якістю викладання є системний підхід, а не разове анкетування. Тільки в такому випадку можливо проводити порівняльну аналітичну роботу, отримувати більш об’єктивну інформацію, яка може бути використана й як оціночна, і може служити «поштовхом» для підвищення ефективності роботи викладача.

Зауважимо, що неформальні вертикальні мережі, тобто соціальні відносини між керівництвом і підлеглими в формальній ієрархії, виявляються досить важливими для створення сприятливого середовища для висловлювань.
Висновки. 1. Анкетування - складний структурований процес, що має своє функціональне призначення, концептуальні положення, методологію, принципи оброблення отриманих результатів. Стохастичне використання анкетування задля анкетування приносить лише шкоду.

2. Дослідницька функція анкетування передбачає наявність обгрунтованого алгоритму проведення дослідження, спрямованого на вивчення думок, відношень респондентів до проблеми, що вивчається, та проведення прямих і непрямих вимірів.

3. Пропонується змінити логіку конструювання та оброблення даних анкет. Серед переліку запитань важливо забезпечити повторення фрагментів, що направлені на виявлення конкретного факту чи явища, але висловлені іншими словами. Тоді створюється можливість оцінювання валідності опитування саме відносно процесу, що цікавить дослідника [6]. 


\section{Література.}

1. Institutional complexity and organizational responses / Greenwood R., Raynard M., Kodeih F. et al. // Acad. Manag. Ann. - 2011. - № 5 (1). - P. 317-371.

2. Renewal through reorganization: the value of inconsistencies between formal and informal organization / Gulati R., Puranam P. // Organ. Sci. - 2009. № 20 (2). - P. 422-440.

3. Communication in medical records: intergroup language and patient care / Hewett D. G., Watson B. M., Gallois C. et al. // J. Lang. Soc. Psychol. - 2009. - № 28 (2). P. 119-138.

4. Beyond metrics? Utilizing 'soft intelligence' for healthcare quality and safety / Martin G. P., McKee L., Dixon-Woods M. // Soc. Sci. Med. - 2015. № 142. - P. 19-26.

5. More formally: rediscovering the missing link between formal organization and informal social structure / McEvily B., Soda G., Tortoriello M. // Acad. Manag. Ann. - 2014. - № 8 (1). - P. 299-345.

6. Cognitive informatics in biomedicine and healthcare / Patel V. L., Kannampallil Th. G. // Journal of Biomedical Informatics. - 2015. - Vol. 53. - P. 3-14.

7. Анкетирование как механизм мониторинга удовлетворенности внутренних потребителей образовательного процесса / Ворожцова Л. А., Крылов А. С., Кудряшов Ю. В. и др. // Поморский государственный университет им. М. В. Ломоносова, 2011. - Режим доступу: https://narfu.ru > way > vorojcov_kydrjawov.

8. Bond N. Questioning Strategies that Minimize Behavioral Problems / Bond N. // Education Digest. - 2008. Vol. 2. - P. 41-45.

9. Questioning and Its True Values in the Process of Learning and Teaching to Promote Critical Thinking / Shpresa QATIPI // Problems of education in the 21st century. - 2011. - Vol. 38. - P. 71-81.

\section{References.}

1. Greenwood, R., Raynard, M., Kodeih, F., Micelotta, E. R., Lounsbury, M. (2011). Institutional complexity and organizational responses. Acad. Manag. Ann., 5 (1), 317-371.

2. Gulati, R., Puranam, P. (2009). Renewal through reorganization: the value of inconsistencies between formal and informal organization. Organ. Sci., 20 (2), 422-440.

3. Hewett, D. G., Watson, B. M., Gallois, C., Ward, M., Leggett, B. A. (2009). Communication in medical records: intergroup language and patient care. J. Lang. Soc. Psychol., 28 (2). 119-138.

4. Martin, G. P., McKee, L., Dixon-Woods, M. (2015). Beyond metrics? Utilizing 'soft intelligence' for healthcare quality and safety. Soc. Sci. Med., 142, 1926.

5. McEvily, B., Soda, G., Tortoriello, M. (2014). More formally: rediscovering the missing link between formal organization and informal social structure. Acad. Manag. Ann., 8 (1), 299-345.

6. Patel, V. L., Kannampallil, Th. G. (2015). Cognitive informatics in biomedicine and healthcare. Journal of Biomedical Informatics, Volume 53, 3-14.

7. Vorozhcova, L. A., Krylov, A. S., Kudryashov, Yu. V., Rudyuk, E. V., Shestakov, L. N. (2011). Anketirovanie kak mekhanizm monitoringa udovletvorennosti vnutrennih potrebitelej obrazovatel'nogo processa. [Questionnaire as a monitoring mechanism internal consumer satisfaction educational process]. URL: https://narfu.ru/pomorsu.ru/www.pomorsu.ru/_doc/ quality/books/publish/way/vorojcov_kydrjawov.pdf.

8. Bond, N. (2008). Questioning Strategies that Minimize Behavioral Problems. Education Digest, Vol.2, 41-45.

9. Shpresa QATIPI. (2011). Questioning and Its True Values in the Process of Learning and Teaching to Promote Critical Thinking. Problems of education in the 21st century. Volume 38, 71-81. 